\title{
Animation Program History in Fine ART Schools of China
}

\author{
Yang $\mathrm{Cao}^{1}$ \\ ${ }^{1}$ Nanjing Normal University Fine Art School, Nanjing, China \\ Correspondence: Yang Cao, Nanjing Normal University Fine Art School, 1st Wen Yuan Road, Nanjing 210046, \\ Jiangsu, China. Tel: 86-25-8579-4105. E-mail: kent_1019@163.com
}

Received: March 2, 2014 Accepted: March 26, 2014 Online Published: April 14, 2014

doi:10.5539/ach.v6n2p16

URL: http://dx.doi.org/10.5539/ach.v6n2p16

\begin{abstract}
The animation industry of China has developed windingly almost 50 years in 20 century, finally obtained the eruption -like growth in the beginning 21st century. Talent cultivation is one of the important elements of Chinese Animation industry, thus animation education also obtained the stimulation. More and more fine art schools began to have animation program after 2000. This paper studies a brief history of animation professionals in Fine Art Schools of China, and the relationship between fine art schools and animation subject. However the number of schools expanded, but the quantity cannot guarantee quality of education, most Fine art schools are relying on the University-Industry Collaboration teaching mode, but in the fact beneath the brilliant achievements, fine art schools need to sum up teaching experience and education theory different from animation industry. The period of Animation program expanding in Fine Art Schools is almost over, but the period for education quality is coming. How to improve the animation education quality become the most important situation to all Fine Art Schools have animation program.
\end{abstract}

Keywords: animation program, fine art school, animation education

\section{The Background of Animation Program in Fine Art Schools}

After China's animation pioneers produced the first animation short movie Uproar in the Studio by Wan Laiming and Wan Guchan in 1926, The animation industry of China has developed windingly almost 50 years in 20 century, finally obtained the eruption -like growth in the beginning 21 st century. At present, the entire animation industrial of China has 5600 animation companies, produces capacity is 130,000 minutes, and provides 200,000 positions. Talent cultivation is one of the important elements of Chinese Animation industry, thus animation education also obtained the stimulation. More and more fine art schools began to have animation program after 2000. During fifty years from 1949 to 2000 years Chinese animation education maintained by Beijing Film Academy and Communication University of China. From 2000 to 2004, animation department and program were established in nearly 70 schools and institutes. By 2008 according to incomplete statistics, 1300 Teaching and training organizations provided animation education, and animation programs were created in more than 450 colleges and universities (He, 2012).

However the number of schools expanded, but the quantity cannot guarantee the quality of education, because most schools are relying on the University-Industry Collaboration teaching mode. Animation industry of China is mainly original equipment manufacturer as the primary economic characteristic, and therefore animation industry influences Chinese animation education to restrict the creativity and independent of the students.

Currently animation program is mainly set in four disciplines in Chinese Colleges and Universities: Design, Fine Art, Media and Computer. These Colleges and Universities set up animation program with related disciplines in positive preponderance, like some technology institute set animation program focus on computer animation technology and software development, some Fine Art Schools focus on animation drawing. Since a considerable number animation program born out of the original design school or computer science school, so teaching plan formulation deviated the animation talents cultivation requirement from industry, and lack of perpetrate teaching theory and long period education plan (Li \& Zhou, 2009).

From the perspective of Academic qualification, animation education can be summed up four types' level, graduate education, undergraduate education, associate-degree education and certification training. 


\section{The Relationship between Fine Art Schools and Animation}

It is only 14 years history that China fine art Schools offer animation talent cultivation as a special department, but fine art schools are responsible for a valuable role. The animation movie was called art film in China, because animation productions were completed mainly by painting staffs that have artist background. Fine art provides quite important support to animation productions such as: animation character, scene, and color all have the direct relations with the fine art. Therefore animation creation mode becomes a peculiar relationship between fine art and animation. The relationship becomes reason to establish animation program in Fine art schools.

Nowadays Fine art schools provide enrollment to a relatively large number of animation students, and give full play to its own characteristics, and set up teaching mode to educate animation students. Students can practice and learning in the network, the film and Television Film Title Design and cartoon publishing field. But fine art schools are short of film and television courses and environment, hence have limitation to give a comprehensive knowledge to students.

Fine art schools established 3D (three dimensional) animation educations at the same time with classical animation. China did not go through a development process from classical animation to 3D animation education dislike the United States, Britain, Canada and other countries. For most fine art schools to say that 3D animation is a relatively weak strip.

Classical painting is the illusion can be created 3D space in a plane. Part of modern painting are recognized as 2D space painting, at the same time began to turn to the real 3D space, even adding time and movement of four-dimensional space (Shou, 2010). As a modern art action painting is not only ideological and cultural connotation, but also an important content refers to the real space outside the painting, deep affection for the movement of life in space.3D graphic painting provides a virtual world similar to the real world with the three dimension coordinate system. The virtual computer world can communicate and interact with real space like the action painting's extension.

Firstly 3D computer animation is the performance of objects movement in the virtual space. 3D computer animation portrays the virtual character's expression and thinking thoroughly, to succeed in giving life to a virtual character. This is the same kind of desire with the artist Pollock trying to retain traces of life to sense body movement in his painting. Art development cannot be a replacement, but rather enrich means of expression and manifestation.

Computerized 3D animation art inherited the tradition combined both science and Humanities after the Renaissance. Advances in technology allow artist's tools continuously updated. We can assume that, if Rembrandt lived here, then he's going to pick up the camera, he might be a master photographer. If Pollock lives in today, he would be a new media artist with his radical and innovative ability. Pollock might be use motion capture system, using the 3D technology to complement his action painting, consummates him "the overall drawing", causes him to detain truly sinks confuses in the creation and the process of life experience.

\section{A Case Study of Fine Art School Animation Program Development}

Nanjing University fine art school animation program is the Instructive representation in the animation school quantity expanded period. When the first batch of professional animation student enrollment in 2000, only two animated teachers. One teacher is a traditional Chinese painting young teacher with one year training at the Beijing Film Academy. Another teacher is the department head, also is a traditional Chinese painting teacher. Like other Chinese fine art school in this period, actually animation courses are undertaken mainly by traditional artist teachers, and the name of the basic curriculum completely consistent with oil paintings program, Chinese paintings program, such as Introduction to Sketch, Outdoor landscape and Still life painting. And Fine art school did not have concept about animation sketch especially set for the animation.

Since Nanjing University fine art school could not provide full animation courses to students, by the year 2002, most students were not satisfied with the fine art school's curriculum, and the fine art school also received certain pressure therefore the fine art school inducted the University-Industry Collaboration teaching mode, third grade students were sent to ALPHABET Animation Company as internship. At that time NJU fine art school almost give most animation professional courses and hosting management rights to the enterprise. Certainly it was effective to gain achievement in a short term, in one year this batch of students became skilled animators in ALPHABET Company. In the company students created and produced a number of animated films, and some films obtained chance to broadcast in Taiwan and the Japanese channels, even got some Animation Awards. One year later Nanjing University fine art school graduate students employment rates reached $100 \%$. In 2004 relied on these achievements, Nanjing University fine art school was ranked as top five schools in the Chinese animation 
education sector.

Nanjing University fine art school's animation talents cultivation idea was anxious to achieve quick success and get instant benefits, but time periodic rule of animation talents cultivation was overlooked. Time periodic rule of animation talents cultivation should be a systematic and lengthy process, including Training periods, practice periods, understanding periods and promotion periods.

The training period is the process of animation system to learn the knowledge. Students need to seize certain basic knowledge and basic skills in the process of animation industry.

The Practice period is the term for application of the knowledge and skills into the actual work acquired from training period. Students correct insufficient animation theory study.

Understand the period refers to discover problems, existing knowledge in the first two period of learning. Students could continue to improve and develop their own creative talent.

The promotion periods request cultivating all-round animation talents. Students practice to carry on the animation project, the animation production, even participating enterprise management, the animation capital operation, and the animation product agency.

Nanjing University fine art school animation program is a microcosm of the start-up animation professional Fine Art Schools. Some schools are the potential better than the Nanjing University, some in equivalent level, some even worse.

In fact similar situation happened 20years ago. Although animation industry of China had a great development from 1980 to 1990 relying on Studio training, and produced some classical animation movies, such as STORIES OF AFANTI, MR.BLACK, and MICE SHUKE AND BEITA, animation industry did not cultivate a large number of qualified animation talents. Animation industry was difficult to ongoing and systematic training of talents without specialized educational schools. Thus Fine art schools animation program should consider more own value in the animation talent training.

\section{The Result of Fine Art Schools over Expanding}

At present, the animation talents employment situation is not optimistic. Based on statistic from China Higher Education Student Information and Career Center (CHESICC), the graduated Student employment rate is loitering around $80 \%$, after 2006 animation education expanding period. According the Blue Book 2010 of Report on University Students ' Employment in China, animation programs are classified as undergraduate employment red card (Wang, 2010). The red card means comprehensive Top 10 professional field in high unemployment rate, the employment rate falling, and low monthly wages. From 2010 to 2013 animation program got red card in China. There are two reasons for the most direct:

The first reason is large numbers of smaller companies became an illusion of prosperity, and most of the small companies recession in animation industry.

The second reason is massive Fine art schools and other kind of schools set up the animation program, and student's number in an abundance size. Schools expanded caused the graduates quantity to have the big growth, but the animation professional market demand for talents had no increase following to the graduates quantity. Animation industry staff turnover rate does not appear high value, explained the current animation enterprise human resource flow is relatively stable, so the new talents demand has not increased progressively.

Overall, the quantity and quality of animation industry students training in Fine art school does not adapt with the animation industry and other correlation industry demand.

Analysis from the results of the report, at present the animation industry talented person supply-demand relation overall is supply exceeds demand. Therefore, from the future trend, animation professional employment situation is not optimistic. On the one hand animation industry talent demand has been oversupply; on the other hand fine arts schools and other type of schools set up the animation program to educate a large number of graduates, and professional quality uneven.

\section{Fine art School Animation Program Development Method in China}

In view of above existence question and present situation, animation Education should give more focused on teaching and learning quality, more innovations in teaching method. Animation education development needs inherit the traditional art education and the integration of contemporary concept, and establishes the consummation animation education system gradually by the science manner in order to cultivate high-quality animation design talents needed in the age of digital information. 


\subsection{The Proper Relationship between Art and Technology Animation Education}

Technology and art are compared to two sides of the same coin by Dr. Li Zhengdao. Technical and the artistic which is most important question still are ambiguous in animation education of China. Therefore, the bottleneck in the animation teaching students is how to break the single mode of thinking, and fuse the technology and art organically. Forms the holistic theory is one of the key to solve problem in the animation education. For the purpose of fusing the technology and art organically in animation education, the fundamental solution is to educate the students understand the innovation method that animations are actually manifestations of art based on creativity and production content but the core is the "story telling". Animation technology is creation tools can be using in animation scenes, characters, special effects, rendering the material, etc.

Animation talents cultivation including technology type talents and artistic type talents are not absolute separated. Technology type talents need to comprehend art, and artistic type talents need to control technology. The cultivation goal of China should be focus on unified high-level senior talents with multi-skill needed by the animation industry and market (Wu, 2004).

\subsection{Countermeasure of Optimizing Teaching Mode of Animation}

Fine Art Schools need to adjust education content structure and shift to cross-disciplinary application-oriented education from the simple of artistic education. Fine Art Schools need to break through fogeyish animation creation method in concept art, in-between animation painting, character deign, scene design, effects and other traditional production process, and strengthen the development and application of Internet technology, computer games, film and television technology (Su, , Xie, \& Wang, 2013, p. 179). Fine Art Schools need to increase cross-industry knowledge such as: Webpage design, digital media applications, digital video editing, and $3 \mathrm{G}$ mobile phone video design courses.

Under the condition of without considering using tariffs, $80 \%$ mobile phone user would like to choice portable platform animation in China. From a global perspective, portable platform entertainment services such as mobile phone animation presents the tendency in the fast growth (Wang, 2011).

Faculty formed structure opening-up model education policy. For improved faculty formed structure in teacher training and opening-up to the public, fine art school need to solve existing animation education to organize regular training, and set up special funds for training in-service teachers. Fine art schools also can cooperate with animation company or enterprise, so that employ some experts or technical personnel as external or part-time teacher, not only introduced new ideas consistent form industry, also compensate lack of hands-on practical course teachers and insufficient of teachers practice operation ability. Finally Fine art school Create a teaching gradually links Evolved from classrooms, laboratories, studios, to the company.

According to features of animation professional teaching and application learning orientation, fine art schools should purchase animation laboratory facility construction and equipment. Fine art schools with sufficient enrollment students and well-funded should be appropriate to purchase large-scale professional equipment such as $3 \mathrm{D}$ printer, Render farm and Motion capture apparatus.

Strengthen the cultivation of animation original creativity ability and basic knowledge literacy. Fine art schools need to define the core value of animation is the creation, and original creative ability itself is important channel of employment and entrepreneurship. Fine art schools can be imported international vanguard technology and concept, also persist and carry forward China featured academic with own theory and artistic style, enhance student works more ideology, the artistry, ornamental and entertaining.

Fine art schools need to collect other countries advanced animation education model as learning reference. Stocking type teaching is a certain animation educational model, means students can complete assignment at home, apartment, or the natural environment after teacher has arranged the work, so long as regular and teacher meets, exchanges the work manufacture attainment and the work progress line. This form enable the student to have more opportunity to contact whole world outside the classroom, so that students may go to the library, the avenue, the art museum, the underground station or the ancient road alley to seek the creation inspiration, and complete the work through such link to be able vivid bright, to close the society naturally. Comparing to the captive type teaching students stays all day in front of the computer or in the classroom to complete assignment, stocking type teaching have the obvious different effect (Li \& Zhou, 2009).

\section{References}

He, L. (2012). The thinking about the present situation of Chinese. Animation Education: New Animation Windows 2. 
Li, H., \& Zhou, Y. (2009). Upon the animation education and the innovative learning methods. Journal of Ningbo University (Education Edition), 31(5).

Shou, W. (2010). The spatial expansion from action painting to three dimensional animation new arts. Journal of the National Academy of Art, (1).

$\mathrm{Su}$, J., Xie, Q., \& Wang, N. (2013). The Project teaching reform of animation design in the era of new media. Research and ExplOration in Laboratory, 32(9).

The China Ordinary Higher Education Undergraduate Program. Employment Rate Interval Distribution. Retrieved from http://gaokao.chsi.com.cn/z/jylfb/index2.jsp\#/

Wan, L., \& Wan, G. (n. d.) Uproar in the Studio. Retrieved from http://en.wikipedia.org/wiki/Uproar _in_the_Studio

Wang, B., Zhao, S., Wang, M., Men, Y., \& Da, Y. (2010). Chinese University Students' Employment Report MyCOS Institute. Retrieved from http://daxue.163.com/special/009163A4/mycosjiuye.html

Wang, J. (2011). Discussion on situation of China animation industry and opportunities. Enterprise Economy. $4(368)$.

$\mathrm{Wu}$, J. (2004). Component elements of multi-media teaching. Journal of Shanghai Normal University (Philosophy \& Social Sciences), 33(4).

\section{Copyrights}

Copyright for this article is retained by the author(s), with first publication rights granted to the journal.

This is an open-access article distributed under the terms and conditions of the Creative Commons Attribution license (http://creativecommons.org/licenses/by/3.0/). 